\title{
Efektivitas fungsi pendamping lokal desa dalam pembangunan desa
}

\author{
Asmu Asmu *, Harpin Syah \\ Program Studi Ilmu Pemerintahan Fakultas Ilmu Sosial dan Ilmu Politik, Universitas Muara Bungo \\ * Corresponding Author. E-Mail: asmuumb@gmail.com
}

\begin{tabular}{ll}
\hline \hline \multicolumn{1}{c}{ Info Artikel } & \multicolumn{1}{c}{ Abstrak } \\
\hline \hline Histori Artikel: & Tujuan dilakukan penelitian ini adalah untuk mengetahui efektivitas fungsi pendam- \\
Received: 9 Dec. 2019 & ping lokal desa dalam pembangunan desa di Desa Tunggul Bulin Kecamatan Tabir Ilir \\
Revision: 18 Dec. 2019 & Kabupaten Merangin, serta mengetahui hambatan pendamping lokal desa dalam \\
Accepted: 31 Dec. 2019 & melaksanakan pendampingan dalam pembangunan desa di Desa Tunggul Bulin \\
Kata Kunci: & Kecamatan Tabir Ilir Kabupaten Merangin. Metode yang digunakan dalam penelitian \\
efektivitas; pendamping & ini penelitian ini adalah metode penelitian kualitatif yang bersifat dengan studi \\
lokal desa; pembangunan & deskriptif. Metode yang digunakan dalam penelitian ini penelitian ini adalah metode \\
desa; effectiveness; & penelitian kualitatif yang bersifat dengan studi deskriptif. Teknik pemilihan informan \\
village local assistance; & yang digunakan oleh peneliti dalam penelitian ini adalah dengan menggunakan metode \\
village development & $\begin{array}{l}\text { purposive sampling (teknik penentuan sampel dengan pertimbangan tertentu). Hasil } \\
\text { penelitian ini menunjukkan bahwa fungsi pendamping desa telah efektif dalam }\end{array}$ \\
& pembangunan desa di Desa Tunggul Bulin Kecamatan Tabir Ilir Kabupaten Merangin, \\
& fungsi yang telah dijalankan diantaranya adalah melalui perencanaan pembangunan di \\
& desa dan penyusunan rencana pembangunan desa melalui musyawarah desa, Terkait \\
& dengan kegiatan pembangunan desa, masih belum dapat melaksanakan amanat UU \\
& tersebut terutama terhadap pendampingan yang dilakukan oleh pendamping lokal desa \\
& (PLD), beberapa hambatan PLD dalam menjalankan fungsi pendampingan pembang- \\
& unan Desa Tunggul Bulin Kecamatan Tabir Ilir Kabupaten Merangin, diantaranya \\
& adalah: rendahnya partisipasi masyarakat dan rendahnya kemampuan teknis perangkat \\
& desa, Upaya yang dilakukan pendamping lokal desa dalam mengatasi masalah pem- \\
& bangunan diantaranya adalah meningkatkan partisipasi masyarakat dalam pembangun- \\
& an dan meningkatkan kemampuan perangkat desa, serta menyusun jadwal kegiatan. \\
&
\end{tabular}

The purpose of this study was to determine the effectiveness of the function of the village's local companion in village development in Tunggul Bulin Village, Tabir Ilir District, Merangin District, and to find out the obstacles of the village's local companion in carrying out assistance in village development in Tunggul Bulin Village, Tabir Ilir District, Merangin District. The method used in this study is a qualitative research method that is descriptive in nature. The method used in this study is a qualitative research method that is descriptive in nature. The informant selection technique used by researchers in this study is to use a purposive sampling method (sampling technique with certain considerations). The results of this study indicate that the function of village facilitators has been effective in village development in Tunggul Bulin Village, Tabir Ilir Subdistrict, Merangin District, the functions that have been carried out include through village development planning and preparation of village development plans through village deliberations, related to village development activities, still unable to carry out the mandate of the Act, especially for assistance carried out by local village facilitators (PLD), several PLD obstacles in carrying out the development assistance function of Tunggul Bulin Village, Tabir Ilir Subdistrict, Merangin Regency, including: low community participation and low technical capacity of village officials, efforts what is done by local village facilitators in overcoming development problems include increasing community participation in development and enhancing the capabilities of village officials, and arranging activity schedules.

This work is licensed under a Creative Commons Attribution-ShareAlike 4.0 International License. 
Jurnal Politik dan Pemerintah Daerah, 1 (2), 2019 - 117

Asmu Asmu, Harpin Syah

\section{PENDAHULUAN}

Kehadiran Undang-undang Nomor 6 tahun 2014 tentang Desa menendai babak baru dan perubahan dalam politik pembangunan nasional, dimana desa menjadi titik tumpuh yang mendapatkan perhatian serius (Presiden Republik Indonesia, 2014). Selain itu juga memberikan harapan sekaligus tantangan baru bagi Desa. Dalam undang-undang tersebut pemberdayaan menjadi sebuah misi, tujuan, asas dan agenda kebijakan yang secara prinsip diwujudkan dengan mengakui dan menetapkan kewenangan desa, sementara pemerintah berkewajiban menjamin agar desa mampu melaksanakan upaya pemberdayaan, pembinaan dan pengawasan.

Seperti yang tertuang dalam Pasal 112 Ayat 1 Undang-undang Nomor 6 tahun 2014 tentang Desa, pemerintah, pemerintahan daerah provinsi, dan pemerintah daerah kabupaten atau kota bertugas untuk membina dan mengawasi penyelenggaraan pemerintahan desa. Yang artinya desa haruslah mendapatkan bimbingan, pembinaan, serta pengawasan didalam menyelenggarakan pemerintahan, pembangunan dan pelayanannya terhadap masyarakat sekaligus memberdayakan masyarakat itu sendiri (Khaerunnisa, 2019; Presiden Republik Indonesia, 2014; Yuslaini \& Juliana, 2019).

Pembangunan Desa dilaksanakan dengan konsep Pemberdayaan Masyarakat Desa dengan tujuan mengembangkan kemandirian dan kesejahteraan masyarakat dengan meningkatkan pengetahuan, sikap, keterampilan, perilaku, kemampuan, kesadaran, serta memanfaatkan sumber daya melalui penetapan kebijakan, program, kegiatan, dan pendampingan yang sesuai dengan esensi masalah dan prioritas kebutuhan masyarakat Desa. Pemberdayaan masyarakat Desa dilaksanakan dengan pendampingan dalam perencanaan, pelaksanaan, dan pemantauan pembangunan Desa dan kawasan Perdesaan (Presiden Republik Indonesia, 2014; Suswanto, et.al., 2019).

Pendampingan Desa adalah kegiatan untuk melakukan tindakan pemberdayaan masyarakat melalui asistensi, pengorganisasian, pengarahan dan fasilitasi Desa (Presiden Republik Indonesia, 2014). Dalam upaya peningkatan kualitas hidup dan kehidupan untuk sebesar-besarnya kesejahteraan masyarakat desa (Presiden Republik Indonesia, 2014).

Pendamping desa juga memegang peran penting dalam mendorong pendayagunaan lembaga kemasyarakatan Desa dan lembaga adat. Bukan tugas yang mudah, karena selama ini dibanyak tempat, lembaga kemasyarakatan seakan hanya lembaga papan nama saja. Kondisi ini terjadi karena memang lembaga kemasyarakatan di desa tidak pernah mendapat sentuhan. Di Program Nasional Pemberdayaan Masyarakat Perdesaan, Lembaga Pemberdayaan Masyarakat, salah satu lembaga kemasyarakatan ini baru disentuh setelah konsep integrasi digaungkan pada awal 2011. Tidak kalah penting, pendamping desa juga dituntut mendorong partisipasi masyarakat dalam penyusunan kebijakan Desa yang dilakukan melalui musyawarah Desa. Kebijakan-kebijakan strategis yang berkaitan dengan desa, utamanya pengelolaan pembangunan desa, harus dipertanggungjawabkan melalui musyawarah desa.

Selanjutnya, Pendamping desa juga bertugas mendorong pengawasan dan pemantauan penyelenggaraan Pemerintahan desa dan pembangunan Desa yang dilakukan secara partisipatif oleh masyarakat Desa. Pengawasan secara kelembagaan menjadi tugas utama Badan Permusyawaratan Desa dan secara partisipatif menjadi hak dan kewajiban masyarakat desa. Karena itu mendorong penguatan fungsi Badan Permusyawaratan Desa sehingga otonomi desa merupakan otonomi yang asli, bulat dan utuh (Widjaya, 2012, p. 165).

Tahap selanjutnya, pendamping desa bahkan dituntut untuk melakukan penyadaran kepada masyarakat desa akan hak dan kewajibannya sebagai warga desa. Pada tahap ini, pendamping desa harus memerankan diri sebagai community organizer yang harus jeli membaca fenomena hubungan sosial antar kelembagaan dan masyarakat.

Dengan demikian pendamping desa yang dimaksud dapat berhubungan langsung secara intensif dengan pemerintah dan masyarakat desa, menjadi actor yang strategis menuju implementasi UU Desa secara optimal. Pendamping desa adalah kegiatan untuk melakukan tindakan pemberdayaan masyarakat melalui asistensi, pengorganisasian, pengarahan dan fasilitasi desa. Misi besar pendamping desa adalah pemberdayaan masyarakat desa menjadi maju, kuat, mandiri dan demokratis. Kegiatan pendampingan membentang dari pembangunan kapasitas pemerintah, mengorganisasi dan membangun kesadaran kritis masyarakat. Selain itu juga memfasilitasi pembangunan partisipatif, memfasilitasi dan memperkuat musyawarah desa sebagai arena demokrasi dan akuntabilitas lokal hingga mengisi kekosongan antara pemerintah dan masyarakat. Intinya pendampingan desa adalah menciptakan suatu frekuensi yang sama antara pendamping dengan yang didampingi. UU Nomor 6 Tahun 2104 
Jurnal Politik dan Pemerintah Daerah, 1 (2), 2019 - 118

Asmu Asmu, Harpin Syah

mengembangkan paradigma dan konsep baru kebijakan tata kelolah desa secara nasional termasuk mengenai fungsi dan peran pendampingan desa.

Dalam mendamping desa dan melakukan pemberdayaan masyarakat haruslah didampinging oleh pendamping desa yang dimana tenaga pendamping desa yang bertugas di kecamatan untuk mendampingi desa dan mampu mendampingi pendamping lokal desa (PLD).

Berdasarkan observasi awal peneliti di DesaTunggul Bulin Kecamatan Tabir Ilir diketahui bahwa salah satu keluhan tentang petugas Pendamping Desa sebagaimana disuarakan oleh Bapak Laduni selaku Kepala DesaTunggul Bulin. Menurut beliau keberadaan petugas kurang maksimal dalam menjalankan perannya, karena fokus pekerjaan tidak hanya menyasar ke satu desa dikarenakan keterbatasan jumlah pendamping desa yang idealnya satu desa satu pendamping. Sementara untuk wilayah Tabir Ilir sendiri hanya ada dua pendamping desa yang bertugas mendampingi 7 (tujuh) desa, artinya satu pendamping desa diharuskan mampu mendampingi sebanyak 3 hingga 4 desa. Akibatnya, pihak desa merasa bekerja sendirian untuk mewujudkan penyerapan dana desa semaksimal mungkin. ${ }^{1}$

Beliau juga mengatakan, bahwa kondisi georafis desa yang berjauhan menjadi kendala dalam pendampingan yang dilakukan oleh pendamping desa, sehingga jarak tempuh yang cukup jauh tersebut membuat pendampingan kurang maksimal, baik dari segi ketepatan waktu maupun kondisi fisik pendamping yang lelah mengakibatkan pendampingan yang diberikan sekedarnya saja, sekedar memenuhi kewajiban.

Pernyataan yang sama juga disampaikan oleh Bapak Ahmad Kholidi selaku pendamping desa Tunggul Bulin, menurut beliau kendala yang dihadapi dalam pendampingan desa adalah minimnya petugas pendamping desa yang ditempatkan di desa, sehingga pelaksanaan pendampingan kurang maksimal. Karena sepengetahuan beliau bahwa pendampingan desa bukanlah mendampingi pelaksanaan proyek yang masuk ke desa, bukan pula mendampingi dan mengawasi penggunaan Dana Desa, tetapi melakukan pendampingan secara utuh terhadap desa. Pendampingan secara prinsipil berbeda dengan pembinaan. Dalam pembinaan, antara pembina dan yang dibina, mempunyai hubungan yang hirarkhis, sehingga pengetahuan dan kebenaran mengalir satu arah dari atas ke bawah. Sebaliknya dalam pendampingan, para pendamping berdiri setara dengan yang didampingi (stand side by side).

\section{METODE}

\section{Waktu dan Tempat Penelitian}

Sehubungan dengan fokus penelitian yang telah disebutkan diatas Penelitian ini dilakukan di Desa Tunggul Bulin Kecamatan Tabir Ilir Kabupaten Merangin. Pemilihan lokasi tersebut didasari bahwa Desa Tunggul Bulin merupakan salah desa yang belum maksimal dalam hal pendampingan yang dilakukan oleh pendamping desa. Penelitian ini direncanakan pada Bulan Januari hingga Maret 2018.

\section{Jenis Penelitian}

Agar dapat menerapkan metode ilmiah dalam penelitian ini maka diperlukan suatu desain penelitian, yang mampu memahami situasi sosial secara mendalam, menemukan pola dan sesuai dengan kondisi penelitian yang akan dikerjakan. Jenis penelitian yang dilalukan penulis pada penelitian ini adalah jenis penelitian Deskriptif Kualitatif yaitu menggambarkan dan menjelaskan bagaimana keadaan dari objek penelitian berdasarkan fakta-fakta yang ada serta menganalisanya agar bisa menarik suatu kesimpulan.

Dengan demikian penelitian ini akan memberikan suatu gambaran tentang peranan pendamping desa dalam pengawasan dan pembinaan pembangunan desa di Desa Tunggul Bulin Kecamatan Tabir Ilir Kabupaten Merangin.

\section{Teknik Pengumpulan Data}

Untuk memperoleh data yang akurat, relevan, dan dapat di pertanggung jawabkan maka penulis mengunakan beberapa teknik dalam pengumpulan data karena masing masing mempunyai kelebihan dan kekurangan, teknik pengumpulan data dalam penelitian ini, yaitu: (1) Observasi, yaitu pengumpulan data dengan cara mengadakan pengamatan langsung terhadap pendamping desa dalam melaksana-

\footnotetext{
${ }^{1}$ Wawancara, tanggal 7 Desember 2017
} 
kan tugas pendampingan; (2) Wawancara (Interview), yaitu teknik pengumpulan data dimana peneliti secara langsung mengadakan tanya jawab dengan informan yang telah ditentukan; (3) Studi kepustakaan (library research), yaitu dengan membaca dokumen-dokumen, undang-undang dan media informasi lain yang ada hubungannnya dengan pendampingan desa

\section{Teknik Penentuan Informan}

Mengingat data yang diperlukan adalah pedampingan desa dalam pembangunan desa maka pemilihan informan dalam penelitian ini adalah dengan metode purposive sampling (teknik penentuan sampel dengan pertimbangan tertentu) karena dalam teknik proporsive sampling ini teknik penarikan sample secara subjektif dengan maksud atau tujuan tertentu yang mana menganggap bahwa informan yang diambil tersebut memiliki informasi yang diperlukan bagi penelitian yang akan dilakukan.

Adapun informan dalam penelitian ini adalah seperti terlihat pada Tabel 1.

Tabel 1. Informan Penelitian

\begin{tabular}{cllc}
\hline No. & \multicolumn{1}{c}{ Nama } & Jabatan & Jumlah \\
\hline 1. & Aprial Eka Putra, S.E & Pendamping Desa Kecamatan Tabir Ilir & 1 \\
2. & Ahmad Kholidi, S.Pd & Pendamping Lokal Desa Tunggul Bulin & 1 \\
3. & Laduni & Kepala Desa Tunggul Bulin & 1 \\
4. & Khoirul Anwar & Ketua BPD Desa Tunggul Bulin & 1 \\
5. & H.Darwis & Tokoh Adat Desa Tunggul Bulin & 1 \\
6. & Saman & Tokoh Adat Desa Tunggul Bulin & 1 \\
7. & Sargawi & Tokoh Pemuda Desa Tunggul Bulin & 1 \\
8. & Fitriani & Tokoh Perempuan Desa Tunggul Bulin & 1 \\
9. & Samsu & Masyarakat Umum & 1 \\
& & Jumlah & 9 \\
\hline
\end{tabular}

\section{Analisis Data}

Berangkat dari penelitian ini, untuk menganalisis data yang telah dikumpulkan dan diseleksi digunakan teknik analisis data deskriptif-kualitatif, yaitu data-data yang telah dihimpun dan dikumpulkan baik observasi maupun interview (wawancara), selanjutnya disusun, dianalisis, diinterprestasikan untuk kemudian dapat diambil kesimpulan sebagai jawaban atas masalah yang diteliti. Pengambilan kesimpulan dalam penelitian ini dilakukan secara induktif yaitu dari data dan fakta yang khusus, peristiwa-peristiwa yang kongkrit, kemudian dari fakta atau peristiwa yang khusus itu dianalisis ketingkat abstrak yang lebih tinggi.

\section{Jenis Data}

Menurut Sutopo jenis data adalah bentuk data diperoleh dengan menggunakan metode tertentu baik berupa manusia, artefak, ataupun dokumen-dokumen. Menurut Moleong pencatatan sumber data melalui wawancara atau pengamatan merupakan hasil gabungan dari kegiatan melihat, mendengar, dan bertanya (Moleong, 2007). Pada penelitian kualitatif, kegiatan-kegiatan ini dilakukan secara sadar, terarah dan senantiasa bertujuan memperoleh suatu informasi yang diperlukan. Berbagai sumber data yang akan dimanfaatkan dalam penelitian ini sebagai berikut.

Data Primer

Data primer adalah data yang diperoleh langsung dari sumbernya. Data primer dalam penelitian ini diperoleh dari wawancara dan observasi.

\section{Data Sekunder}

Data sekunder dalam penelitian ini adalah data yang diperoleh bukan secara langsung dari sumbernya. Penelitian ini sumber data sekunder yang dipakai adalah sumber tertulis seperti sumber buku, laporan pendamping desa, laporan pembangunan desa, dan dokumen-dokumen lain yang relevan dengan penelitian ini.

\section{HASIL DAN PEMBAHASAN}

Efektivitas Fungsi Pendamping Lokal Desa Dalam Pembangunan Desa di Desa Tunggul Bulin Kecamatan Tabir Ilir Kabupaten Merangin 
Undang-undang Nomor 6 Tahun 2014 tentang Desa telah jelas menegaskan bawha pemberdayaan masyarakat desa sebagaimana dilaksanakan dengan pendampingan dalam perencanaan, pelaksanaan, dan pemantauan pembangunan desa dan kawasan perdesaan. Sehingga pemerintah berkewajiban untuk memberikan pendampingan kepada desa dalam rangka pemberdayaan masyarakat desa, besarnya alokasi dana desa yang akan mengalir ke desa, melalui pendamping proses musyawarah desa membentuk RPJM (rencana pembangunan jangka menengah desa)/RKP (rencana kerja pemerintah desa), maka anggaran tersebut dapat dipergunakan secara tepat sasaran sesuai kebutuhan pembangunan desa.

Pemberdayaan dilakukan dengan pendampingan dalam perencanaan, pelaksanaan dan pemantauan pembangunan desa dan kawasan perdesaan. Pendampingan Masyarakat Desa sebagaimana dalam PP No 43 tahun 2014 diperjelas dan pertegas pada pasal 129 yaitu sebagai berikut: Tenaga pendamping profesional terdiri atas: (1) pendamping Desa yang bertugas mendampingi Desa dalam penyelenggaraan Pemerintahan Desa, kerja sama Desa, pengembangan BUM Desa, dan pembangunan yang berskala lokal Desa; (2) pendamping teknis yang bertugas mendampingi Desa dalam pelaksanaan program dan kegiatan sektoral; dan (3) tenaga ahli pemberdayaan masyarakat yang bertugas meningkatkan kapasitas tenaga pendamping dalam rangka penyelenggaraan Pemerintahan Desa, pelaksanaan pembangunan Desa, pembinaan kemasyarakatan Desa, dan pemberdayaan masyarakat Desa (Presiden Republik Indonesia, 2014a).

Sering kali terdengar sebuah pertanyaan "apa peran pendamping desa?" dengan nada sinis dan penuh kecurigaan. Seolah tanpa adanya pendampingan, maka pembangunan dan pemberdayaan akan tetap berjalan dengan sendirinya, bukankah sudah ada aturan yang harus diikuti dan banyaknya mata yang mengawasi ke desa akhir-akhir ini, sehingga seharusnya tidak ada masalah dan kegiatan di desa tetap berjalan seperti biasanya.

Jika kita melihat dari dua hal, yang pertama, soal akhir kegiatan yang dapat dilaksanakan oleh desa, dan kedua, soal anggaran yang harus dikeluarkan untuk menggaji pendamping yang dapat di hemat, semua kesimpulan yang diambil diatas mungkin terasa benar. Namun jika kita bicara soal kualitas dari dana desa atau alokasi dana desa tanpa pendampingan, sudahkah inklusifitas tercipta di dalam APBDesa? Dimana setiap sudut desa merasakan manfaat dari dana desa tersebut, baik sebagai pelaku ataupun objek pembangunan.

Kemudian, cukup dengan aturan maka desa sudah tertib, apakah artinya kita sudah menghargai hak-hak desa yang ada didalam UU No 6 tahun 2014 tentang desa dengan beragam turunannya? Dimana setiap tahun, prioritas dana desa haruslah dibuat peraturannya yang disesuaikan dengan pencapaian yang dilakukan tahun sebelumnya, misalnya, jika jalan desa sepanjang satu juta kilometer telah terbangun, darimanakah dana perbaikannya dimasa depan seandainya UU desa dicabut atau direvisi sesuai kondisi negara dimasa depan.

Melakukan pemberdayaan di dalam lingkup desa, berarti ada penyamaan persepsi pembangunan yang sama diantara 74.754 desa se Indonesia dengan dinamika masyarakat yang bisa saja berbeda antara satu kabupaten dengan kabupaten lainnya, bahkan dalam lingkup antar dusunpun dapat berbeda persepsi, mungkin disatu desa, posisi matrilinier masih kental terasa, atau suara ninik mamak yang harus didengarkan daripada suara seorang camat sekalipun, ditempat lain mungkin kita dapat berbicara lugas tanpa batasan, di sisi lain, tutur kata haruslah dijaga untuk menghormati tuan rumah

Menyamakan seluruh desa, bahwa dana desa untuk menciptakan inklusifitas tanpa memandang perbedaan kelamin, ras, suku bangsa itu secara teori mungkin terasa mudah, namun sayangnya, watak manusia tidak hanya tergambar dengan mudah oleh zodiak atau shio yang bisa diramal setiap saat. Mensosialisasikan tentang UU No 6 tahun 2014 kepada masyarakat desa bukanlah hal yang mudah, karena dalam proses sosialiasi ini, kita ikut serta membangunkan kesadaran masyarakat desa untuk membangun desanya sendiri. Efektivitas fungsi pendamping lokal desa dalam pembangunan desa di Desa Tunggul Bulin Kecamatan Tabir Ilir Kabupaten Merangin dilihat berdasarkan teori Sondang P. Siagian, dimana efektivitas kerja organisasi sangat tergantung dari efektivitas kerja dari orang-orang yang bekerja didalamnya. Ada beberapa kriteria yang dapat digunakan untuk mengukur efektivitas kerja dari organisasi dalam memberikan pelayanan antara lain :

\section{Faktor Waktu}

Faktor waktu di sini maksudnya adalah ketepatan waktu dan kecepatan waktu dari pelayanan yang diberikan oleh pemberi pelayanan. Hanya saja penggunaan ukuran tentang tepat tidaknya atau 
cepat tidaknya pelayanan yang diberikan berbeda dari satu orang ke orang lain. Terlepas dari penilaian subjektif yang demikian, yang jelas ialah faktor waktu dapat dijadikan sebagai salah satu ukuran efektivitas kerja.

Berdasarkan hasil wawancara dengan beberapa informan diketahui bahwa faktor waktu pendampingan yang diberikan pendamping desa dalam pembangunan desa di Desa Tunggul Bulin Kecamatan Tabir Ilir Kabupaten Merangin sudah efektif hanya saja belum maksimal, hal ini terlihat dari lambannya proses perencanaan pembangunan. Hal ini sebagaimana disampaikan oleh Bapak Laduni selaku Kepala Desa Tunggul Bulin:

“....sebenarnya sudah efektif, hanya saja belum maksimal, kalau soal waktu, bukan kesalahan dari Pendamping desa sebenarnya, kesalahan itu ada pada masyarakat, karena kalau rapat susah sekali kumpulnya..."

Beliau melanjutkan:

“..seharusnya perencanaan desa telah selesai pada Bulan Desember namun molor hingga bulan Januari tahun berikutnya..." 3

Pemerintah Desa menyusun perencanaan Pembangunan Desa sesuai dengan kewenangannya dengan mengacu pada perencanaan pembangunan Kabupaten/Kota. Perencanaan dan Pembangunan Desa dilaksanakan oleh Pemerintah Desa dengan melibatkan seluruh masyarakat Desa dengan semangat gotong royong. Masyarakat Desa berhak melakukan pemantauan terhadap pelaksanaan Pembangunan Desa.

Dalam rangka perencanaan dan pelaksanaan pembangunan Desa, pemerintah Desa didampingi oleh pemerintah daerah kabupaten/kota yang secara teknis dilaksanakan oleh satuan kerja perangkat daerah kabupaten/kota. Untuk mengoordinasikan pembangunan Desa, kepala desa dapat didampingi oleh tenaga pendamping profesional, kader pemberdayaan masyarakat Desa, dan/atau pihak ketiga.

Seperti di desa-desa yang lain, diakhir tahun setiap desa di Kecamatan Tabir Ilir juga mengadakan kegiatan Musrenbangdes atau musyawarah rencana pembangunan desa untuk setahun yang akan datang (2019). Pemerintah Desa Tunggul Bulin menggelar Musyawarah Rencana Pembangunan Desa (Musrenbangdes). Musyawarah yang dilaksanakan di Aula Balai Desa Tunggul Bulin pada tanggal 29 Januari 2018, dihadiri oleh Kepala Desa beserta Perangkat Desa, Kasi PMD Kecamatan Tabir Ilir, BPD, LPMD, Kepala Dusun, KPMD, Kader PKK, PLD, serta perwakilan Tokoh Masyarakat dan Tokoh Agama. Hal ini sebagaimana disampaikan oleh Kepala Desa Tunggul Bulin Bapak Laduni saat wawancara dengan peneliti, berikut penuturannya:

"Musrenbangdes itu kan dilaksanakan sebelum Musrenbang Kecamatan, biasanya dilaksanakan akhir tahun, namun karena beberapa tahapan yang belum dilaksanakan terpaksa mundur hingga Januari maren..."

Pernyataan tersebut menggambarkan bahwa pelaksanaan musrenbangdes di Desa Tunggul Bulin belum sepenuhnya berjlaan sesuai waktu yang telah ditetapkan. Kondisi tersebut dibenarkan oleh Ahmad Kholidi, S.Pd selaku pendamping lokal desa, berikut pernyataannya:

“...musrenbangdes itu dilaksanakan pada akhir tahun, sedangkan Musrenbang Kecamatan awal tahun, berhubungan pada akhir tahun 2017 beberapa tahapan belum dilaksanakan terpaksa molor hingga bulan Januari berikutnya, sebab musyawarah perencanaan itukan berjenjang, dari musywarah dusun, musywarah kelompok baru musyarawah desa." 5

\section{Faktor kecermatan}

Faktor kecermatan dapat dijadikan ukuran untuk menilai tingkat efektivitas kerja organisasi yang memberikan pelayanan. Faktor kecermatan disini adalah faktor ketelitian dari pemberi pelayanan

\footnotetext{
${ }^{2}$ Wawancara, dengan Bapak Laduni selaku Kepala Desa Tunggul Bulin pada tanggal 8 April 2018

${ }^{3}$ Wawancara, dengan Bapak Laduni selaku Kepala Desa Tunggul Bulin pada tanggal 8 April 2018

${ }^{4}$ Wawancara, dengan Bapak Laduni selaku Kepala Desa Tunggul Bulin pada tanggal 8 April 2018

${ }^{5}$ Wawancara, dengan Ahmad Kholidi, S.Pd selaku Pendamping Lokal Desa Tunggul Bulin pada tanggal 11 April 2018
} 
kepada pelanggan. Pelanggan akan cenderung memberikan nilai yang tidak terlalu tinggi kepada pemberi pelayan, apabila terjadi banyak kesalahan dalam proses pelayanan, meskipun diberikan dalam waktu yang singkat.

Berdasarkan hasil wawancara dengan beberapa informan diketahui bahwa kecermatan pendampingan yang diberikan pendamping desa dalam pembangunan desa di Desa Tunggul Bulin Kecamatan Tabir Ilir Kabupaten Merangin sudah efektif hanya saja belum maksimal, hal ini terlihat dari beberapa permasalahan dalam proses perencanaan pembangunan.

Titik berat dalam permasalahan mayoritas desa bukanlah kurangnya minat partisipasi masyarakat untuk turut andil dalam perencanaan pembangunan desa melalui musyawarah, setelah ditelusuri ternyata dikarenakan mayoritas sumber daya pemerintah desa belum cukup cakap dalam pembuatan dokumen perencanaan desa baik RKPDesa maupun RPJMDesa yang sesuai dengan sistematika dan tahapan penyusunannya. Pemerintah desa mengaku bingung sekalipun sudah mendapatkan pelatihanpelatihan dari SKPD terkait. Fungsi pengawasan dari BPD pun kurang berjalan sehingga adanya pembiaran yang bersifat kritis dalam kinerja pemerintah desa. Hal ini sebagaimana disampaikan oleh Kepala Desa Tunggul Bulin Bapak Laduni saat wawancara dengan peneliti, berikut penuturannya:

“....ketika ditanya kenapa RKPDesa belum selesai ya kami jawab kita tidak tahu cara membuatnya, sistematikanya pun tidak tahu, takut salah, makanya kita menggunakan jasa konsultan." 6

Pernyataan tersebut menggambarkan kondisi yang sebenarnya, dimana kualitas sumber daya manusia perangkat desa belum mampu melaksanakan tugas administrasi yang begitu rumit, hal ini membuktikan bahwa perlunya pendampingan oleh pendamping desa, dengan adanya pendamping diharapkan terjadi peningkatan kualitas SDM perangkat desa sehingga mampu mandiri dalam pembuatan dokumen perencanaan.

Di lain hal, ternyata mayoritas desa-desa binaan menggunakan jasa konsultan dalam pembuatan dokumen desa, dan penganggarannya sudah ada dalam APBDesa. Jadi prakteknya, desa melakukan musyawarah, menggali usulan desa, kemudian tim penyusun mengonsultasikan kembali kepada pemberi jasa

Faktor Gaya Pemberian Pelayanan

Gaya pemberian pelayanan merupakan salah satu ukuran lain yang dapat dan biasanya digunakan dalam mengukur efektivitas kerja. Yang dimaksud dengan gaya disini adalah cara dan kebiasaan pemberi pelayanan dalam memberikan jasa kepada pelanggan. Bisa saja si pelanggan merasa tidak sesuai dengan gaya pelanggan yang diberikan oleh pemberi pelayanan. Jika berbicara tentang sesuatu hal yang menyangkut kesesuaian, sesungguhnya apa yang dibicarakan termasuk hal yang tidak terlepas kaitannya dengan nilai-nilai sosial yang dianut oleh orang yang bersangkutan.

Berdasarkan hasil wawancara dengan beberapa informan diketahui bahwa gaya pemberian pelayanan pendampingan yang diberikan pendamping desa dalam pembangunan desa di Desa Tunggul Bulin Kecamatan Tabir Ilir Kabupaten Merangin sudah efektif, hal ini terlihat dari kemampuan pendamping desa dalam mengatasi permasalahan dalam proses perencanaan pembangunan.

Mayoritas desa-desa binaan menggunakan jasa konsultan dalam pembuatan dokumen desa, dan penganggarannya sudah ada dalam APBDesa. Jadi prakteknya, desa melakukan musyawarah, menggali usulan desa, kemudian tim penyusun mengonsultasikan kembali kepada pemberi jasa

Maka, untuk mengatasi hal ini, sesuai dengan rencana tindak lanjut tenaga pendamping untuk merealiasikan praktek UU Desa, tenaga pendamping desa melakukan inovasi secara bertahap dengan harapan utama: agar desa terbiasa menyelesaikan kebutuhan di desa secara mandiri. Tentu saja jika dianalogikan seperti seorang anak tumbuh dewasa dan makin dewasa melewati masa waktu dan pembelajaran untuk bisa mandiri, perlu usaha keras dari dirinya sendiri dan didukung oleh lingkungan sekitar untuk bisa mandiri. Sebagaimana disampaikan oleh Aprial Eka Putra, S.E selaku Pendamping Desa Kecamatan Tabir Ilir, berikut penuturannya:

“...setelah kita mengevaluasi terhadap penyusunan perencanaan desa yang dilakukan beberapa desa dalam wilayah kecamatan Tabir Ilir termasuk Desa Tunggul Bulin, maka kita berupaya

\footnotetext{
${ }^{6}$ Wawancara, dengan Bapak Laduni selaku Kepala Desa Tunggul Bulin pada tanggal 8 April 2018
} 
Jurnal Politik dan Pemerintah Daerah, 1 (2), 2019 - 123

Asmu Asmu, Harpin Syah

membenahinya, kita lakukan pendampingan agar dikemudian hari pemerintah desa benar-benar bisa merencanakan pembangunan sendiri, tidak perlu menggunakan jasa konsultan, karena yang tahu tentang kebutuhan desa tentunya pemerintah desa itu sendiri..."

Hasil wawancara tersebut membuktikan bahwa keberadaan pendamping lokal desa sangat efektif dalam membina pemerintahan desa dalam mengupayakan perangkat desa yang berkualitas, karena efektivitas merupakan salah satu dimensi dari produktivitas, yaitu mengarah kepada pencapaian unjuk kerja yang maksimal, yaitu pencapaian target yang berkaitan dengan kualitas, kuantitas dan waktu.

Selanjutnya beliau menambahkan:

“...Agar harapan ini terwujud tentu saja bukan hanya menjadi tugas saya dan rekan-rekan saya sebagai tenaga pendamping dalam memfasilitasi perencanaan pembangunan desa agar berjalan sesuai tahapan dan regulasi saja, tetapi juga perlunya kerjasama dan pengawasan yang optimal dari pihak Kecamatan serta Kabupaten. Tentu berbicara kemandirian, artinya berbicara perubahan. Apa yang perlu dirubah? Pola pikir..." 8

Sungguh benar sekali apa yang telah disampaikan oleh Aprial Eka Putra, S.E selaku Pendamping Desa Kecamatan Tabir Ilir, karena kemampuan pendamping desa sangat terbatas, baik dari sisi waktu maupun biaya transportasi dalam kunjungan, maka diperlukan partisipasi aktif dari berbagai pihak, baik itu kecamatan maupun kabupaten, agar sama ikut membenahi pola pikir perangkat desa maupun masyarakat desa itu sendiri.

Pendapat yang sama juga dibenarkan oleh Ahmad Kholidi, S.Pd selaku pendamping lokal desa, berikut pernyataannya:

"Rasanya seperti melakukan pekerjaan yang hampir mustahil. Untuk mengubah sistem pola pikir dan kinerja yang ideal tidak semudah membalikkan telapak tangan, jadi apa yang kami lakukan di Kecamatan Tabir Ilir adalah tidak lepas dari fasilitasi yang bersifat pembinaan kapasitas pemerintah desa secara berkala, kunjungan door to door dari desa ke desa untuk pelatihan atau bimbingan teknis, serta bermodel in class dan sosialisasi mengenai Pembuatan RPJMDesa dan RKPDesa bekerjasama dengan pihak Kecamatan dan tenaga ahli kabupaten.."9

Pendapatan tersebut memang benar adanya, dimana masyarakat desa sangat sulit sekali untuk merubah perilaku apatis yang melekat pada mereka, dimana umumnya masyarakat desa kurang peduli terhadap perencanaan pembangunan maupun pengawasan pembangunan, mereka lebih mementingkan kehidupan mereka sendiri dengan dalih bahwa pembangunan desa itu merupakan tanggung jawab pemerintah desa dan pemerintah daerah.

Selanjutnya beliau menambahkan:

“....alhamdulilah berkat kerja keras kita bersama perjalanan di tahun 2017, ketika kemampuan dan wawasan yang sudah dimiliki, dan sumber daya yang semakin terbekali, munculnya rasa kesadaran pemerintah desa akan pentingnya efisiensi dan efektifitas dalam bunyi regulasi pada pedoman pembangunan desa. Misi dan ketegasan UU Desa tidak disepelekan seperti angin lalu, penyelesaikan dokumenpun hampir tidak lagi jauh terlambat dan permasalahan pun tidak terlalu signifikan, sekalipun pemahaman dan keterampilan desa akan pembuatan hal berunsur teknis seperti rencana anggaran biaya dan desain gambar masih kurang memadai dalam sumber dayanya...." 10

Hal tersebut telah menunjukan hasil, meskipun belum maksimal namun telah memulai sebuah perubahan pradigma bagi pemerintah desa dan masyarakat, dimana pembangunan desa bukan sekedar

\footnotetext{
${ }^{7}$ Wawancara, dengan Aprial Eka Putra, S.E selaku Pendamping Desa Kecamatan Tabir Ilir Tunggul Bulin pada tanggal 11 April 2018

${ }^{8}$ Wawancara, dengan Aprial Eka Putra, S.E selaku Pendamping Desa Kecamatan Tabir Ilir Tunggul Bulin pada tanggal 11 April 2018

${ }^{9}$ Wawancara, dengan Ahmad Kholidi, S.Pd selaku Pendamping Lokal Desa Tunggul Bulin pada tanggal 11 April 2018

${ }^{10}$ Wawancara, dengan Ahmad Kholidi, S.Pd selaku Pendamping Lokal Desa Tunggul Bulin pada tanggal 11 April 2018
} 
membangun fisik saja, namun juga membangun sumber daya manusianya, maka pembekalan dan pembinaan merupakan langkah awal dalam membentuk masyarakat yang partisipatif dan tidak tinggal diam dalam ikut serta membangun desanya.

Pernyataan tersebut dibenarkan oleh Kepala Desa Tunggul Bulin Bapak Laduni saat wawancara dengan peneliti, berikut penuturannya:

"kami bersyukur sekali dengan adanya pendamping desa ini, baik pendamping desa (PD) maupun pendamping lokal desa (PLD)nya aktif membimbing kami, meskipun sedikit kesusahan karena kita minim sumber daya manusianya." 11

Pendapat tersebut telah menggambarkan secara jelas bahwa kehadiran pendamping desa maupun pendamping lokal desa memberikan dampak besar bagi aparatur pemerintah desa maupun masyarakat itu sendiri, karena salah satu tugas pendamping desa adalah melakukan peningkatan kapasitas bagi Pemerintahan Desa, lembaga kemasyarakatan Desa dalam hal pembangunan dan pemberdayaan masyarakat Desa. ${ }^{12}$

\section{Hambatan Pendamping Desa dalam melaksanakan pendampingan dalam pembangunan desa di Desa Tunggul Bulin Kecamatan Tabir Ilir Kabupaten Merangin}

Berdasarkan hasil wawancara dan observasi di Desa Desa Tunggul Bulin Kecamatan Tabir Ilir diketahui bahwa terkait dengan kegiatan pembangunan desa, masih belum dapat melaksanakan amanat UU tersebut terutama terhadap pendampingan yang dilakukan oleh pendamping lokal desa (PLD), beberapa hambatan Pendamping Lokal Desa (PLD) dalam menjalankan fungsi pendampingan pembangunan Desa Tunggul Bulin Kecamatan Tabir Ilir Kabupaten Merangin, diantaranya adalah:

Rendahnya Partisipasi Masyarakat

Memang selama ini Desa Tunggul Bulin sudah bisa melaksanakan perencanaan pembangunan, namun umumnya masih belum secara partisipatif. Selama ini Desa Tunggul Bulin melaksanakan perencanaan pembangunan secara elitis yaitu sepenuhnya dilakukan oleh pemerintahan desa, baik dilaksanakan sendiri oleh kepala desa, aparat desa, dan BPD, maupun dilakukan oleh orang yang menjadi konsultan dalam perencanaan pembangunan desa. Namun sejak bebarapa tahun terakhir sudah melibatkan masyarakat dalam melaksanakan perencanaan pembangunan yaitu melalui mekanisme musrenbangdes, walaupun belum maksimal. Hal ini sebagaimana disampaikan oleh Aprial Eka Putra, S.E selaku Pendamping Desa Kecamatan Tabir Ilir:

"Selama ini perencanaan pembangunan desa di Desa Tunggul Bulin dilakukan oleh kepala desa, aparat desa, dan BPD, dan biasanya melibatkan orang yang ahli seperi pegawai pada Kantor Camat Tabir Ilir, namun sejak adanya pendampingan yang dilakukan oleh pendamping desa, sudah banyak kemajuan, diantaranya melalui musyawarah perencanaan pembangunan desa (Musrenbangdes).. ${ }^{13}$

Pernyataan tersebut menunjukan bahwa konsep pembangunan desa telah menempatkan perlakuan terhadap masyarakat dalam pembangunan pada posisi yang begitu berarti dan sentral. Sehingga keterlibatannya dalam proses pembangunan menjadi titik penentu apakah proses pembangunan itu menjadi wahana proses belajar atau hanya sekedar sebuah rekayasa yang mana pemerintah menjadi pemain tunggal. Dengan demikian penekanan pada aspek "proses" memiliki arti penting. Proses belajar mengandung makna bahwa setiap kekurangan dan kelemahan yang muncul dalam proses pelaksanaan program pembangunan menjadi informasi yang penting dan untuk itu dilakukan upayaupaya penanggulangannya.

Selanjutnya beliau menambahkan:

"Namun sayangnya, belum semua komponen masyarakat diundang dalam kegiatan tersebut. Pada umumnya yang diundang dalam musrenbangdes adalah tokoh-tokoh masyarakat saja, baik tokoh

\footnotetext{
${ }^{11}$ Wawancara, dengan Bapak Laduni selaku Kepala Desa Tunggul Bulin pada tanggal 8 April 2018

${ }^{12}$ Pasal 12 Permendes Nomor 3 Tahun 2015

${ }^{13}$ Wawancara, dengan Aprial Eka Putra, S.E selaku Pendamping Desa Kecamatan Tabir Ilir Tunggul Bulin pada tanggal 11 April 2018
} 
Jurnal Politik dan Pemerintah Daerah, 1 (2), 2019 - 125

Asmu Asmu, Harpin Syah

masyarakat yang bersifat formal yaitu mereka yang menjabat sebagai kepala dusun dan perangkat desa maupun tokoh masyarakat yang bersifat nonformal misalnya tokoh agama. ${ }^{14}$ Bulin:

Hal ini juga dibenarkan oleh Ahmad Kholidi, S.Pd selaku Pendamping Lokal Desa Tunggul

"Banyak yang diundang, namun seringkali pemerintah desa lupa untuk mengundang warga masyarakat yang dikelompokkan sebagai "kelompok rentan" yaitu mereka yang tergolong sebagai minoritas, miskin, difabel dan perempuan. Kalaupun mereka yang tergolong dalam kelompok rentan tersebut diundang dalam musrenbangdes, biasanya mereka tidak bisa menyampaikan aspirasinya, baik karena minder sehingga tidak mampu bicara maupun karena aspirasi mereka tidak tertampung karena tidak dianggap oleh mayoritas peserta musrenbang. " 15

Pernyataan tersebut berkesesuaian dengan pernyataan H. Darwis selaku Tokoh Adat Tunggul Bulin, berikut ketetangannya:

“...tidak semua diundang, biasanya yang diundang tokoh-tokohnya saja, padahal yang membutuhkan pembangunan itu adalah masyarakat itu sendiri, kalau tokoh masyarakat itu kan belum tentu paham semua kondisi di daerahnya"16

Berdasarkan pernyataan tersebut terlihat bahwa tidak semua unsur masyarakat diundang, jika pun datang banyak yang tidak memberikan aspirasi karena takut bicara atau minder, sehingga dampak yang terjadi akibat perencanaan pembangunan yang belum partisipatif adalah pelaksanaan pembangunan desa yang selama ini dilaksanakan oleh sebagian besar desa-desa di Indonesia belum bisa dirasakan manfaatnya oleh seluruh lapisan masyarakat. Padahal pelaksanaan pembangunan desa belum bisa dikatakan berhasil bila masih ada sebagian warga masyarakat yang belum bisa merasakan manfaat dari pelaksanaan pembangunan tersebut.

Hal tersebut juga dibenarkan oleh Sargawi selaku Tokoh Pemuda Tunggul Bulin, berikut penjelasannya:

“..kami pemuda jarang diundang, kadang di undang bukan pengurus inti, namun mereka yang dekat dengan kepala desa, padahal pemuda juga butuh dengan dukungan dari pemerintah desa dalam pembinaan dan pembanugnan di bidang olah raga.." 17

Tentu semua pihak berharap pelaksanaan pembangunan di desa bisa dirasakan manfaatnya oleh seluruh warga masyarakat di desa, dan tidak ada satupun warga masyarakat yang merasa terabaikan, sehingga cita-cita luhur para pendiri bangsa ini, yaitu terciptanya masyarakat yang sejahtera, adil makmur dan merata dapat segera diwujudkan.

Rendahnya Kemampuan Teknis Perangkat Desa

Permasalahan lain yang menjadi hambatan Pendamping Lokal Desa (PLD) dalam menjalankan fungsi pendampingan pada proses penyusunan dokumen perencanaan pembangunan Desa Tunggul Bulin adalah kurangnya kemampuan teknis perencanaan pembangunan desa, tercermin dari dokumendokumen perencanaan desa yang belum lengkap. Hal ini sebagiamana disampaikan oleh Aprial Eka Putra, S.E selaku Pendamping Desa Kecamatan Tabir Ilir, berikut keterangannya:

“..masalah lain yang menjadi kendalah bagi PLD di lapangan adalah mengenai rendahnya kemampuan teknis perangkat desa, hal ini terlihat dari dokumen perencanaan pembangunan yang

\footnotetext{
${ }^{14}$ Wawancara, dengan Aprial Eka Putra, S.E selaku Pendamping Desa Kecamatan Tabir Ilir Tunggul Bulin pada tanggal 11 April 2018

15 Wawancara, dengan Ahmad Kholidi, S.Pd selaku Pendamping Lokal Desa Tunggul Bulin pada tanggal 11 April 2018

${ }^{16}$ Wawancara, dengan H.Darwis selaku Tokoh Adat Tunggul Bulin tanggal 20 April 2018

${ }^{17}$ Wawancara, dengan Sargawi selaku Tokoh Pemuda Tunggul Bulin tanggal 20 April 2018
} 
belum lengkap, terkadang mereka tidak menyimpan arsip, yang lebih disayangkan jika ada pergantian pegawai maka data tersebut sudah tidak ada lagi.." 18

Selain itu belum semua desa dalam Kecamatan Tabir Ilir menyusun RPJMDes, namun demikian desa sudah menyusun RKP Desa, padahal untuk menyusun RKP Desa seharusnya mengacu pada RPJMDes. Hal ini sebagaimana disampaikan oleh Aprial Eka Putra, S.E selaku Pendamping Desa Kecamatan Tabir Ilir:

“...banyak desa yang belum menyusun RPJMDes, namun mereka sudah selesai membuat RKP

Desa, padahal tersusunnya RKP Desa tersebut menimbulkan tanda tanya, bagaimana mungkin Desa dapat menyusun RKP Desa, sedangkan RPJMDes belum mereka susun.." 19

Selain itu pelaksanaan Musrenbang Desa di Desa Tunggul Bulin tidak berlangsung secara optimal. Adanya keterbatasan anggaran juga berpengaruh besar pada penyusunan anggaran pendapatan dan belanja desa (APBDes). Adanya loncatan-loncatan dalam penyusunan dokumen perencanaan pembangunan tersebut memperlihatkan, bahwa pada dasarnya pemahaman teknis perencanaan pembangunan desa yang dimiliki perangkat desa Desa Tunggul Bulin belum memadai karena perangkat desa belum dibekali dengan diklat/bintek yang diperlukan, sehingga perangkat desa hanya melakukan kegiatan-kegiatan secara rutin seperti tahun-tahun sebelumnya, padahal kebijakan mekanisme perencanaan pembangunan desa sudah mengalami perubahan yang sangat mendasar.

Luasnya Wilayah Pendampingan/Binaan

Permasalahan lain yang menjadi hambatan Pendamping Lokal Desa (PLD) dalam menjalankan fungsi pendampingan adalah luasnya wilayah pendampingan, dikarenakan jarak satu desa dengan desa lainnya yang cukup jauh, hal ini sebagaimana disampaikan oleh Ahmad Kholidi, S.Pd selaku Pendamping Lokal Desa Tunggul Bulin:

“yang menjadi kendala utama kita juga adalah luasnya wilayah kerja kita, sebab desa di sini kan jaraknya jauh-jauh antara satu desa dengan desa lain." 20

Pernyataan tersebut menggambarkan bahwa wilayah kerja Pendamping Lokal Desa tidak hanya satu desa, namun beberapa desa dalam wilayah Kecamatan Tabir Ilir, sehingga jarak antar desa yang jauh tersebut terkadang menjadi kendala bagi pendamping dalam melakukan pendampingan.

Kemudian beliau melanjutkan:

“...kebiasaan masyarakat di desa-desa sini, jika melakukan pertemuan itu di malam hari, dikarenakan siang hari banyak yang ke ladang, atau ke kebun menyadap karet, kalau pulang dah larut malam..jadi itu kendala, sehingga terkadang kami terpaksa membatalkan hadir.." ${ }^{21}$

Kondisi tersebut menggambarkan bahwa struktur wilayah yang luas menjadi kendala bagi pendamping lokal desa dalam pendampingan, selain itu adat kebiasaan masyarakat yang kumpul di malam hari juga menjadi penghambat. Sehingga mengakibatkan pendampingan Desa dalam perencanaan, pelaksanaan, dan pemantauan terhadap pembangunan Desa dan pemberdayaan masyarakat Desa tidak dapat berjalan dengan maksimal.

Minimnya honor Pendamping Lokal Desa

Permasalahan lain yang menjadi hambatan Pendamping Lokal Desa (PLD) dalam menjalankan fungsi pendampingan pada proses penyusunan dokumen perencanaan pembangunan Desa Tunggul

\footnotetext{
${ }^{18}$ Wawancara, dengan Aprial Eka Putra, S.E selaku Pendamping Desa Kecamatan Tabir Ilir Tunggul Bulin pada tanggal 11 April 2018

${ }^{19}$ Wawancara, dengan Aprial Eka Putra, S.E selaku Pendamping Desa Kecamatan Tabir Ilir Tunggul Bulin pada tanggal 11 April 2018

${ }^{20}$ Wawancara, dengan Ahmad Kholidi, S.Pd selaku Pendamping Lokal Desa Tunggul Bulin pada tanggal 11 April 2018

${ }^{21}$ Wawancara, dengan Ahmad Kholidi, S.Pd selaku Pendamping Lokal Desa Tunggul Bulin pada tanggal 11 April 2018
} 
Jurnal Politik dan Pemerintah Daerah, 1 (2), 2019 - 127

Asmu Asmu, Harpin Syah

Bulin adalah minimnya honor yang diterima pendamping lokal desa. Hal ini juga dibenarkan oleh Ahmad Kholidi, S.Pd selaku Pendamping Lokal Desa Tunggul Bulin:

“..bukannya kami tidak mensyukuri namun memang honor yang kita terima masih sangat minim, sehingga hal tersebut menjadi kendala, adapun honor yang kita terima lebih kurang 2,2 juta, semuanya biaya yang diperlukan melebihi dari angka tersebut, karena kita tidak ada biaya berjalanan dinas, sementara kita seminggu hampir 5 kali melakukan kunjungan ke desa-desa, meskipun desa yang berbeda-beda." 22

\section{Upaya Pendamping Lokal Desa dalam Mengatasi Masalah Pembangunan}

Berdasarkan wawancara dengan pendamping lokal Desa Tunggul Bulin Kecamatan Tabir Ilir Kabupaten Merangin upaya yang dilakukan Pendamping Lokal Desa dalam mengatasi masalah pembangunan diantarnya adalah:

Meningkatkan Partisipasi Masyarakat dalam Pembangunan

Menurut Pendamping Lokal Desa Tunggul Bulin, pemerintah desa tidak boleh ketergantungan dengan Pendamping Lokal Desa, pemerintah desa harus mengupayakan meningkatkan partisipasi masyarakat dalam pembangunan, karena keterlibatan masyarakat secara aktif akan membantu pemerintah desa dalam merencanakan, melaksanakan, dan mengawasi pembangunan itu sendiri. Hal ini sebagaimana disampaikan Ahmad Kholidi, S.Pd selaku Pendamping Lokal Desa Tunggul Bulin, berikut penuturannya:

“...kita tidak bisa hanya mengandalkan PD dan PLD saja, jumlah mereka terbatas, desa yang dilakukan pendampingan cukup banyak, maka upaya kita adalah mendorong partisipasi masyarakat itu sendiri, dari perencanaan, pelaksanaan, hingga pengawasan, dengan seperti itu diharapkan pembangunan Desa Tunggul Bulin dapat berjalan sesuai harapan bersama.." 23

Ahmad Kholidi, S.Pd selaku Pendamping Lokal Desa Tunggul Bulin menuturkan beberapa alasan rendahnya partisipasi masyarakat dalam perencanaan pembangunan yaitu kurangnya sosialisasi tentang perencanaan pembangunan menyebabkan mereka tidak hadir dalam proses perencanaan pembangunan melalui musyawarah perencanaan pembangunan desa. Berikut penjelasanya:

“...Kurangnya kepedulian dengan pembangunan itu sendiri dilihat dari kurangnya antusiasme masyarakat dalam memberi masukan dan mengkritik proses perencanaan pembangunan. Kesibukan bekerja menjadi alasan utama masyarakat untuk tidak hadir dalam musrenbang desa. Sulit memang mengumpulkan masyarakat untuk merumuskan masalah dan kebutuhan pembangunan desa, tidak sedikit dari mereka yang tidak mengerti tujuan dari kegiatan ini. ${ }^{24}$

Hal yang sama juga disampaikan oleh Bapak Laduni selaku Kepala Desa Tunggul Bulin, menurut beliau rendahnya partisipasi masyarakat dalam proses perencanaan pembangunan dipengaruhi oleh beberapa faktor: ${ }^{25}$ (1) Keterbatasan masyarakat terhadap pemahaman perencanaan pembangunan; (2) Adanya sikap pesimis masyarakat terhadap proses perencanaan pembangunan karena usulan-usulan mereka tidak terakomodasi dalam proses yang lebih tinggi; (3) Terbatasnya jumlah kader dan aparat pemerintah desa yang bertugas mengkomunikasikan informasi mengenai perencanaan pembangunan kepada masyarakat; (4) Waktu penyelenggaraan perencanaan pembangunan yang relatif pendek sehingga tidak seimbang dengan materi yang harus dibahas dan diputuskan.

\footnotetext{
${ }^{22}$ Wawancara, dengan Ahmad Kholidi, S.Pd selaku Pendamping Lokal Desa Tunggul Bulin pada tanggal 11 April 2018

${ }^{23}$ Wawancara, dengan Ahmad Kholidi, S.Pd selaku Pendamping Lokal Desa Tunggul Bulin pada tanggal 11 April 2018

${ }^{24}$ Wawancara, dengan Ahmad Kholidi, S.Pd selaku Pendamping Lokal Desa Tunggul Bulin pada tanggal 11 April 2018

${ }^{25}$ Wawancara, dengan Bapak Laduni selaku Kepala Desa Tunggul Bulin pada tanggal 8 April 2018
} 
Meningkatkan Kemampuan Perangkat Desa

Upaya lain yang dilakukan pemerintah desa dalam mengatasi masalah kurangnya jumlah pendamping desa adalah dengan meningkatkan kemampuan perangkat desa, hal ini sebagaimana disampaikan oleh Bapak Laduni selaku Kepala Desa Tunggul Bulin, berikut penjelasanya:

“...upaya yang kita lakukan bersama Pendamping Lokal Desa adalah dalam meningkatkan kemampuan desa dengan memberikan bimbingan teknis kepada sekretaris desa dan kepala urusan pemerintahan. kegiatan tersebut dilakukan dalam rangka meningkatkan kemandirian desa baik dalam perencenaan maupun pelaksanaan pembangunan." 26

Pernyataan tersebut menggambarkan bahwa Pendamping Lokal Desa Tunggul Bulin telah menjalankan tugasnya, khususnya melakukan peningkatan kapasitas bagi Pemerintahan Desa, lembaga kemasyarakatan Desa dalam hal pembangunan dan pemberdayaan masyarakat Desa.

Selanjutnya beliau menambakan:

"perangkat desa dituntut mampu membuat Rancangan Anggaran Belanja (RAB) yang benar, sehingga nanti tidak menghambat terhadap pelaksaan pembangunan yang bakan dilakukan. Dari mulai perencanaan, realisasi hingga peloporan harus dilakukan dengan benar, makanya kita terus motivasi, bina dan beri peningkatan kemampuan dalam pengelolaan anggaran, "27

Pendapat yang sama disampaikan oleh Ahmad Kholidi, S.Pd selaku Pendamping Lokal Desa Tunggul Bulin, berikut penuturannya:

“....dengan semakin banyaknya aturan baru tentang pengelolaan keuangan desa, menuntut kemampuan perangkat desa harus terus ditingkatkan. Pada dasarnya perangkat desa sudah mampu melaksanakan pengadministrasian, namun karena banyak aturan baru dari pusat, membuat mereka harus terus meningkatkan kemampuanya",28

Selanjutnya beliau menambahkan bahwa pihaknya akan terus meningkatkan kapasitas dan tugasnya. Tugas pokok Pendamping Desa yang utama adalah mengawal implementasi UU Desa dengan memperkuat proses pelaksanaan pemberdayaan masyarakat desa.

"Kita terus fasilitasi desa-desa agar dalam pelaksanaanya pembangunan desa bisa berjalan dengan lancar, sehingga masyarakat bisa merasakan kesejahteraan, "29

Efektivitas pembangunan pada hakikatnya merupakan tindakan membandingkan antara perencanaan dengan hasil. Antara kedua hal tersebut sering terjadi penyimpangan. Tugas PLD adalah mengoreksi penyimpangan tersebut. Pembangunan desa adalah strategi pembangunan bagi peningkatan kehidupan ekonomi dan sosial dari kelompok khusus masyarakat, dalam hal ini masyarakat kurang mampu di pedesaan. Pembangunan desa bertujuan mengurangi kemiskinan serta tersedianya sarana dan prasarana umum untuk menunjang segala kebutuhan masyarakat yang ternyata masih kurang untuk membantu masyarakat desa dalam beraktivitas sehari-hari.

Pengaturan Jadwal Pertemuan

Upaya yang dilakukan Pendamping Lokal Desa (PLD) dalam dalam mengatasi masalah pembangunan karena luasnya wilayah pendampingan, dikarenakan jarak satu desa dengan desa lainnya yang cukup jauh, adalah dengan mengatur jadwal ulang pertemuan, hal ini sebagaimana disampaikan oleh Ahmad Kholidi, S.Pd selaku Pendamping Lokal Desa Tunggul Bulin:

"karena desanya jauh-jauh maka kami mengupayakan dengan mengatur jadwal pertemuan, sehingga semua desa dapat dihadiri, serta mengupayakan pertemuan disiang hari, ini bertujuan agar kami bisa mengikuti semua kegiatan di desa." 30

\footnotetext{
${ }^{26}$ Wawancara, dengan Bapak Laduni selaku Kepala Desa Tunggul Bulin pada tanggal 8 April 2018

${ }^{27}$ Wawancara, dengan Bapak Laduni selaku Kepala Desa Tunggul Bulin pada tanggal 8 April 2018

${ }^{28}$ Wawancara, dengan Ahmad Kholidi, S.Pd selaku Pendamping Lokal Desa Tunggul Bulin pada tanggal 11 April 2018

${ }^{29}$ Wawancara, dengan Ahmad Kholidi, S.Pd selaku Pendamping Lokal Desa Tunggul Bulin pada tanggal 11 April 2018
} 
Upaya yang telah dilakukan tersebut menggambarkan bahwa Pendamping Lokal Desa Tunggul Bulin memiliki kepekaan terhadap kebiasaan, adat istiadat dan nilai-nilai budaya masyarakat Desa sebagaimana yang disyaratkan mengenai Kompetensi pendamping Desa.

Berdasarkan keterangan dari Ahmad Kholidi, S.Pd selaku Pendamping Lokal Desa Tunggul Bulin diketahui bahwa PLD diwajibkan membuat rencana kerja setiap akhir bulan untuk dilaksanakan pada bulan berikutnya, hal ini sebagaimana disampaikan oleh beliau:

“..diakhir bulan kita sudah menyelesaikan rencana kegiatan kita untuk bulan berikutnya, rencana kegiatan tersebut diketahui oleh Camat dan diverifikasi langsung oleh Pendamping Desa Kecamatan Tabir Ilir, jadi bukan asal kita buat saja, nah, dalam rencana kerja tersebut jelas lokasi yang akan kita kunjungi dan kegiatannya apa saja serta hasil yang akan dicapai dari kegiatan tersebut." 31

Pernyataan tersebut menunjukan bahwa tingkat kehadiran PLD tergantung dari jadwal yang telah dibuat oleh PLD itu sendiri berdasarkan rencana pembangunan secara nasional dengan memperhatikan kondisi di lapangan dan jumlah desa yang menjadi pertimbangan dalam penyusunan jadwal dimaksud.

\section{SIMPULAN}

Fungsi pendamping telah efektif dalam pembangunan desa di Desa Tunggul Bulin Kecamatan Tabir Ilir Kabupaten Merangin. Ada beberapa kriteria yang dapat digunakan untuk mengukur efektivitas kerja dari organisasi dalam memberikan pelayanan antara lain: faktor waktu, faktor kecermatan, dan faktor gaya pemberian pelayanan.

Beberapa hambatan Pendamping Lokal Desa (PLD) dalam menjalankan fungsi pendampingan pembangunan Desa Tunggul Bulin Kecamatan Tabir Ilir Kabupaten Merangin, diantaranya adalah: rendahnya partisipasi masyarakat, rendahnya kemampuan teknis perangkat desa, dan luasnya wilayah pendampingan/binaan.

Upaya yang dilakukan Pendamping Lokal Desa dalam mengatasi masalah pembangunan diantaranya adalah: meningkatkan partisipasi masyarakat dalam pembangunan, meningkatkan kemampuan perangkat desa, dan pengaturan jadwal pertemuan.

\section{Saran}

Salah satu tugas dan peran penting dari pendamping desa adalah membantu desa membentuk dan memanfaatkan jaringan sosial serta mengembangkan kerjasama, baik kerjasama antar desa maupun dengan pihak ketiga guna mewujudkan tujuan dari pembangunan desa, sebagaimana dinyatakan dalam UU Desa, untuk itu diharapkan pendamping lokal desa dapat menjalin kerjasama dengan berbagai pihak demi terlaksananya pembangunan desa yang lebih baik.

Perlunya peran aktif dari pemerintah desa untuk mengikuti setiap arahan dari pendamping lokal desa guna dapat mandiri dalam pembangunan. Diharapkan pendamping lokal desa dapat meningkatkan peran serta masyarakat dalam perencanaan pembangunan, sehingga dapat mewujudkan pembangunan yang partisipatif .

\section{DAFTAR PUSTAKA}

Khaerunnisa, K. (2019). Peran BPD dan Pemerintah Desa dalam Penyelenggaraan Pembangunan Desa Secara Demokratis Menurut Undang-undang no. 6 tahun 2014 tentang Desa (Studi Desa Wellulang Kec. Amali Kab. Bone). Jurnal Al-Dustur, 2(1).

Moleong, L. J. (2007). Metode penelitian kualitatif. Bandung: PT Remaja Rosdakarya

Presiden Republik Indonesia. (2014). Undang-Undang Republik Indonesia Nomor 6 Tahun 2014 Tentang Desa

${ }^{30}$ Wawancara, dengan Ahmad Kholidi, S.Pd selaku Pendamping Lokal Desa Tunggul Bulin pada tanggal 11 April 2018

${ }^{31}$ Wawancara, dengan Ahmad Kholidi, S.Pd selaku Pendamping Lokal Desa Tunggul Bulin pada tanggal 11 April 2018 
Jurnal Politik dan Pemerintah Daerah, 1 (2), 2019 - 130

Asmu Asmu, Harpin Syah

Presiden Republik Indonesia. (2014a). Peraturan Pemerintah Republik Indonesia Nomor 43 Tahun 2014 Tentang Peraturan Pelaksanaan Undang-Undang Nomor 6 Tahun 2014 tentang desa

Suswanto, B., Windiasih, R., Sulaiman, A. I., \& Weningsih, S. (2019). Peran Pendamping Desa Dalam Model Pemberdayaan Masyarakat Berkelanjutan. Jurnal Sosial Soedirman, 2(2), 40-60.

Widjaja, H. A. W. (2012). Otonomi desa merupakan otonomi yang asli, bulat, dan utuh. Divisi Buku Perguruan Tinggi, Raja Grafindo Persada.

Yuslaini, N., \& Juliana, S. (2019). Evaluasi program pendamping desa di Kabupaten Bengkalis. WEDANA: Jurnal Kajian Pemerintahan, Politik dan Birokrasi, 5(2), 7-15. 